\title{
Barn som tar sitt liv, noen tanker omkring funn gjort i en psykologisk autopsistudie Av Anne Freuchen
}

Hensikten med studien var å øke vår kunnskap om barn og unge som tar sitt liv: Hvilke risikofaktorer og omstendigheter i livene deres finner vi? Har de noen fellestrekk som gjør det mulig å gjenkjenne de som er i faresonen? 


\section{Metode}

I tidsperioden 2007-2009 giennomførte vi en psykologisk autopsistudie på barn og ungdom, 15 år og yngre, som var døde ved selvmord i Norge, sammenliknet med barn og ungdom i samme alder som var døde ved ulykker (Freuchen, Kjelsberg, Lundervold, \& Groholt, 2012). Metoden psykologisk autopsi innebærer innhenting av informasjon om den avdøde fra flere informanter og kilder. I denne studien var barnas foreldre hovedinformanter. I tillegg innhentet vi informasjon fra sykehusjournaler, politi- og obduksjonsrapporter.

Interviuene med foreldrene i selvmord- og ulykkesgruppen hadde form av en samtale, ansikt til ansikt, hjemme hos dem eller et annet sted foreldrene valgte. Hele Norge var representert i begge gruppene, fra Mandal i sør til Kirkenes i nord. Alle interviuene ble foretatt av undertegnede i perioden 2007-2009. Jeg opplevde alltid å bli tatt vel imot.Vi benyttet internasjonalt anerkjente instrumenter validerte for norske forhold: Schedule for Affective Disorders and Schizophrenia for School Aged Children (6-18 years): Present and Lifetime Version (KIDDIE-SADSPL), et semistrukturert diagnostisk interviu (Kaufman et al., 1997), Strengths and Difficulties Questionnaire (SDQ) (Goodman, 1997) og Children's Global Assessment scale (C-GAS) (Shaffer et al., 1983).

\section{Materiale}

Fra Statistisk Sentralbyrå (SSB) fikk vi oppgitt de 91 barn og unge, 15 år og yngre, hvis død var klassifisert som selvmord i perioden 1993-2004, hvorav 42 (46\%) av en av foreldrene eller foreldreparene sa ja til å delta i studien. Som sammenlikningsgruppe ble valgt barn og unge, 15 år og yngre, som døde i ulykker i samme periode. Dødsfall ved naturkatastrofer og ulykker hvor barnet var passasjer i båt, bil, buss eller fly ble ekskludert. Hensikten var å ha en sammenlikningsgruppe hvor bl.a. hukommelsesskjevhet, dvs. måten foreldrene ville huske barnet på, kunne være tilnærmet lik, idet det også i ulykkesgruppen dreide seg om plutselige og uventede dødsfall som lå tilbake i tid. Fra SSB fikk vi oppgitt 96 barn og unge som var døde i ulykker i perioden 1993-2004, hvorav 42 (44\%) av foreldrene eller foreldreparene sa ja til å delta i studien.

I tillegg til ulykkesgruppen som sammenlikningsgruppe, fikk vi data fra Barn i Bergen-studien (BiB). Dette er en stor prospektiv studie med deltagelse av skolebarn i Bergen. Fra BiB-studien ble det giort et tilfeldig utvalg på 410 barn, matchet for kjønn og alder i forhold til selvmordsgruppen $\left(^{*}\right)$. Selvmordsgruppen ble sammenliknet med BiB-gruppen på enkelte variabler.

\begin{tabular}{|c|c|c|c|c|c|}
\hline & Populasjon (n) & Tidsrom & $\begin{array}{l}\text { Utvalg, dvs.foreldre } \\
\text { som deltok (n) }\end{array}$ & $\begin{array}{l}\text { Barnets alder, gjennomsnitt } \\
\text { (spredning) }\end{array}$ & Kjønn \\
\hline Død i selvmord & 91 & 1993-2004 & 42 (46 \%) & 14,3 år (11,7-15,9 år) & $71 \%$ gutter \\
\hline Død i ulykke & 96 & 1993-2004 & $42(44 \%)$ & 13,2 år (10,0-15,5 år) & $52 \%$ gutter \\
\hline Barn i Bergen* & $\begin{array}{l}7007 \text { (1. runde) } \\
5781 \text { (2. runde) } \\
1721 \text { (3. runde) }\end{array}$ & 2002-2008 & 410 & 14,3 år (11,7-15,9 år) & $71 \%$ gutter \\
\hline
\end{tabular}


I dette innlegget onsker jeg å trekke frem og reflektere over noen av de statistisk signifikante forskjellene mellom selvmordsgruppen og ulykkesgruppen, eller mellom selvmordsgruppen og BiB-gruppen (angitt som Pearson's chi-kvadrat, med signifikansnivå p<.05), og noen interessante tilfeller av manglende signifikante forskjeller. Det er viktig å være klar over at vi ikke kan generalisere ut fra de aktuelle funnene til alle selvmord blant barn og ungdom, 15 år og yngre, til det var deltagelsen for lav.

\section{- Lik sine jevnaldrende}

Barna i selvmordsgruppen og ulykkesgruppen var svært like mht. sosiodemografiske variabler så som antall flyttinger, bytte av nærmiliø, skolebytter, separerte eller skilte foreldre eller hvem de bodde hos eller sammen med. Det var ingen signifikante forskjeller på fødselslengde eller -vekt. Lav fødselsvekt kan predikere okt risiko for suicid (Mittendorfer-Rutz, Rasmussen, \& Wasserman, 2004).

\section{- Psykisk sykdom}

Når det gjaldt psykisk sykdom, vurdert med KIDDIESADS-PL, fant vi ingen signifikante forskieller mellom gruppene. Vi hadde ved oppstart av studien en hypotese om at vi i selvmordsgruppen ville finne en overrepresentasion av triste barn, og slik sett var funnet uventet. Derfor så vi nærmere på hva og hvordan foreldrene hadde svart på spørsmålene som tar for seg symptomer på depresion. Da fant vi at $30 \%$ av selvmordsbarna hadde hatt en Sub-terskel depresion, mot $10 \%$ av ulykkesbarna (p $\leq .01$ ). Sub-terskel depresion er definert som en tilstand hvor det diagnostiske hovedkriteriet for depresion er tilfredsstilt, men ikke tilleggskriteriene (Fergusson, Horwood, Ridder, \& Beautrais, 2005). Funnet tyder på at de barna som tok livet sitt var noe tristere, dvs. oftere hadde depressive symptomer, enn sine jevnaldrende, men at de ikke hadde det som i psykiatrien ville bli definert som en depresion. Kanskje var dette også årsaken til at de ikke var eller hadde vært pasienter i barne- og ungdomspsykiatrien oftere enn sine jevnaldrende i ulykkesgruppen.

\section{- Selvmordsatferd}

Foreldrene ble spurt hvorvidt eller i hvilken grad barnet hadde vist selvmordsatferd. Dette begrepet innebærer vanligvis selvmordstanker, -planer eller -forsøk. Av naturlige årsaker kunne vi ikke få informasjon om barnets selvmordstanker eller -planer, med mindre disse var formidlet til foreldrene. Således spurte vi foreldrene hvorvidt de hadde merket at barnet hadde vist større interesse for temaet selvmord, (ved å ha lest bøker, dikt, sett filmer om selvmord, hørt på Heavy Metal-musikk hvor tekstene ofte omhandler selvdestruktiv atferd og selvmord, eller skrevet om temaet), enn for eksempel søsknene. Flere foreldre i selvmordsgruppen (48\%) enn i ulykkesgruppen ( $2 \%$ ) fortalte om slik interesse ( $\mathrm{p} \leq . \mathrm{O}$ ). De barna som senere tok sitt liv hadde også oftere tidligere giort selvmordsfors $ø \mathrm{k}$ som foreldrene kjente til, enn barna i ulykkesgruppen ( $p=.02$ ).

- Konflikt eller vanskelig situasion

Vi fant at barna i selvmordsgruppen oftere hadde vært i en konfliktsituasion kort tid forut for sin død (6o \% i selvmordsgruppen vs. $12 \%$ i ulykkesgruppen, $\mathrm{p} \leq . \mathrm{o1}$ ). De hadde ikke søkt hielp hos foreldrene for å løse konflikten eller den vanskelige situasjonen, heller ikke i de tilfellene der foreldrene ikke var del av konflikten. Tidsintervallet mellom oppstått konflikt og selvmordshandlingen var kort, i de fleste tilfellene fra en halv time til noen få timer.

\section{- Mobbing}

I nær en tredjedel (29\%) av selvmordsgruppen oppga foreldrene at barnet var blitt mobbet, uten at vi gikk nærmere inn på alvorlighetsgrad av mobbingen. Dette var en større andel enn i ulykkesgruppen (14\%), men forskjellen var ikke statistisk signifikant. Sammenliknet med BiB-gruppen (9\%) var selvmordsgruppen signifikant oftere utsatt for mobbing $(\mathrm{p} \leq .01)$.

\section{Noen betraktninger om funnene i denne studien}

\section{Lik sine jevnaldrende}

De symptomene og risikofaktorene vi vanligvis ser hos eldre selvmordstruet ungdom, var lite fremtredende hos denne yngste aldersgruppen. Det er derfor vanskeligere å gienkjenne dem som er i faresonen. Foreldrene beskrev endringer i stemningsleie og atferd, og de rapporterte om konflikter, men dette så de i etterkant av selvmordet, ikke på det tidspunktet da endringene pågikk.

\section{Psykisk sykdom}

Hele $30 \%$ i selvmordsgruppen hadde en sub-terskel depresion. De hadde altså et nedsatt stemningsleie og viste mangel på interesse. Studier viser at sub-terskel depresjon gir en forhøyet risiko for både senere depresjon og selvmordsatferd (Fergusson et al., 2005). Således er denne tilstanden noe vi skal være oppmerksomme på, ikke bare se etter en fullt ut utviklet depresjon. Barn og unge har ikke den erfaringen og referanserammen som vi voksne har. Mange vanskelige situasjoner opplever de for første gang, og de vet ikke hvordan de skal takle det. Vi voksne må se barnet, avdekke og gienkjenne tristhet og mistrivsel og vi må snakke med barnet eller ungdommen om det vi ser. Vi skal ikke alltid tenke at det går nok over, selv om det som oftest giør nettopp det.

\section{Selvmordsatferd}

Vi fant en økt interesse for temaet selvmord i selvmordsgruppen. Dette er et utmerket utgangspunkt for foreldre til å ta opp viktige spørsmål i samtaler med sine barn om medgang, motgang, liv og død. I min mangeårige kliniske praksis med barn og unge har jeg ofte opplevd at barnet eller ungdommen har virket nesten forundret over at livet deres skal by på vanskeligheter ellet tristhet, utover det som raskt går over. Deres umiddelbare tanke var ofte at dette triste, denne angsten eller motgangen, det var de alene om å oppleve og slik de hadde det nå, slik ville det alltid være. For noen ble dette en kime til selvmordstanker og -planer.

Jeg tror mange foreldre i den hensikt å beskytte barnet, unngår vanskelige temaer. Det de oppnår er at barnet blir uforberedt på hva livet vil bringe, ikke bare av gleder, men også av motgang og vansker. Det er viktig å snakke med barna om ulike måter å møte og løse vansker på. Vi må formidle at det alltid vil finnes alternative løsninger, og vi må fortelle dem hvor eller hos hvem de kan søke råd. 


\section{Konflikt eller vanskelig situasjon}

Hele $60 \%$ i selvmordsgruppen var i en konfliktsituasion. Det var snakk om det vi voksne vil vurdere som ikke spesielt alvorlige situasjoner eller problemer; tatt i nasking for små beløp, jukset på en prøve, bli urettmessig beskyldt for noe, etc. Dette er situasjoner som ville kunne løses giennom enkle tiltak. Shaffer fant at unge selvmordsofre ofte hadde en misforstått oppfatning mht konsekvensene av den konflikten eller situasjonen de var i forut for selvmordet (Shaffer et al., 1996). Barna søkte ikke råd eller støtte hos foreldrene som først i etterkant ble oppmerksomme på konflikten. En studie viser at ungdom søker støtte hos venner når de er i vansker, de går ikke til sine foresatte (Groholt, Ekeberg, Wichstrom, \& Haldorsen, 1998). Vi hadde ikke informasion om hvorvidt barna hadde bedt venner om hielp.

En utrygg tilknytning mellom barn og forelder innebærer at barnet har erfart usikkerhet i forhold til om forelderen vil være der til støtte og hjelp når det er behov for det (Bowlby, 1988). I en norsk studie er det beskrevet hvordan depressive symptomer kan se ut til å være et resultat av utrygg tilknytning (Sund \& Wichstrom, 2002). Sheftall og medarbeidere fant en sammenheng mellom utrygg tilknytning og selvmordsfors $ø$ k hos ungdom i alderen 13-18 år (Sheftall, Schoppe-Sullivan, \& Bridge, 2014). Vi kan ikke si noe om tilknytningsmønster i forhold til deltagerne i vår studie, det lå utenfor studiens rammer. Tilknytningsproblematikk sett i sammenheng med selvmordsproblematikk er et viktig tema for videre forskning.

\section{Mobbing}

Nær en tredjedel av foreldrene i selvmordsgruppen fortalte at barnet hadde blitt mobbet. Vårt datamateriale er fra perioden 1993-2004, og det dreide seg derfor i all hovedsak om direkte mobbing ansikt til ansikt. I dag ville mobbingen artet seg annerledes, med langt flere mobbearenaer og større distanse mellom mobber og mobbeoffer («cyber-mobbing» med mobiltelefon, sms, mms, sosiale nettverk, etc.).

Vi vet stadig mer om hvordan mobbing kan innvirke på et ungt, sårbart og uferdig sinn, og hvilke konsekvenser det kan få. Forskning på feltet viser at både det å være mobber og mobbeoffer ser ut til å oke risikoen for depresjon, selvmordstanker og selvmordsforsøk (Brunstein, Marrocco, Kleinman, Schonfeld, \& Gould, 2007; Klomek Vi må være inte- et al., 2009). Konklusjonen må være at mobbing, uavressert i våre barn, hengig av form, alltid skal til forskjell fra å tas alvorlig. Ansvaret for å intervenere må ligge hos de være nysgjerrige. $\quad$ voksne. Når barn forteller Samtalen på senge- om mobbing må de erfare å kanten, bruk den. bli hørt og at den voksne giør noe med situasionen.

I en misforstått respekt for barnets eller ungdommens integritet godtar vi for lett deres avvisning i forhold til ikke å ville fortelle om hva de opplever i hverdagen. Hvordan kan vi ivareta vårt ansvar som omsorgspersoner dersom vi ikke vet hva som foregår i barnets liv og tankeverden. Jeg vil avslutte med å referere det en far ba meg formidle: Vi må være interessert i våre barn, til forskjell fra å være nysgierrige.

Samtalen på sengekanten, bruk den.
Bowlby, I. (1988). Developmental psychiatry comes of age. Am.J.Psychiatry, 145(1), 1-10.

Brunstein, K. A., Marrocco, F., Kleinman, M., Schonfeld, I. S., \& Gould, M. S. (2007). Bullying, depression, and suicidality in adolescents. I.Am.Acad.Child Adolesc.Psychiatry, 46(1), 40-49. doi: 10.1097/01.chi.0000242237.84925.18 [doi];:So89o-8567(og)61956-o [pii]

Fergusson, D. M., Horwood, L. I., Ridder, E. M., \& Beautrais, A. L. (2005). Sub threshold depression in adolescence and mental health outcomes in adulthood. Arch.Gen.Psychiatry, 62(1), 66-72. doi: 62/1/66 [pii];10.1001/archpsyc.62.1.66 [doi]

Freuchen, A., Kielsberg, E., Lundervold, A. I., \& Groholt, B. (2012). Differences between children and adolescents who commit suicide and their peers: $A$ psychological autopsy of suicide victims compared to accident victims and a community sample. Child Adolesc.Psychiatry Ment.Health, 6(1), 1. doi: 17532000-6-1 [pii];10.1186/1753-2000-6-1 [doi]

Goodman, R. (1997). The Strengths and Difficulties Questionnaire: a research note. I.Child Psychol.Psychiatry, 38(5), 581-586.

Groholt, B., Ekeberg, O., Wichstrom, L., \& Haldorsen, T. (1998). Suicide among children and younger and older adolescents in Norway: a comparative study. I.Am.Acad.Child Adolesc.Psychiatry, 37(5), 473-481.

Kaufman, I., Birmaher, B., Brent, D., Rao, U., Flynn, C., Moreci, P., . . Ryan, N. (1997). Schedule for Affective Disorders and Schizophrenia for School-Age Children-Present and Lifetime Version (K-SADS-PL): initial reliability and validity data. I.Am.Acad.Child Adolesc.Psychiatry, 36(7), 980-988.

Klomek, A. B., Sourander, A., Niemela, S., Kumpulainen, K., Piha, J., Tamminen, T..... Gould, M. S. (2009). Childhood bullying behaviors as a risk for suicide attempts and completed suicides: a population-based birth cohort study. I.Am.Acad.Child Adolesc.Psychiatry, 48(3), 254-261. doi: 10.1097/CHI.oborze318196bg1f [doi];So89o-8567(og)60025-3 [pii]

Mittendorfer-Rutz, E., Rasmussen, F., \& Wasserman, D. (2004). Restricted fe tal growth and adverse maternal psychosocial and socioeconomic conditi ons as risk factors for suicidal behaviour of offspring: a cohort study. Lancet, 364(9440), 1135-1140. doi: 10.1016/so140-6736(o4)17099-2

Shaffer, D., Gould, M. S., Brasic, I., Ambrosini, P., Fisher, P., Bird, H., \& Aluwahlia, S. (1983). A children's global assessment scale (CGAS). Archives of General Psychiatry, 40(11), 1228-1231.

Shaffer, D., Gould, M. S., Fisher, P., Trautman, P., Moreau, D., Kleinman, M., \& Flory, M. (1996). Psychiatric diagnosis in child and adolescent suicide. Arch.Gen. Psychiatry, 53(4), 339-348.

Sheftall, A. H., Schoppe-Sullivan, S. I., \& Bridge, I. A. (2014). Insecure attachment and suicidal behavior in adolescents. Crisis, 35(6), 426-430. doi: 10.1027/0227$5910 / 9000273$

Sund, A. M., \& Wichstrom, L. (2002). Insecure attachment as a risk factor for future depressive symptoms in early adolescence. I.Am.Acad.Child Adolesc.Psychiatry, 41(12), 1478-1485. doi: So89o-8567(og)60743-7 [pii];10.1097/00004583200212000-00020 [doi]

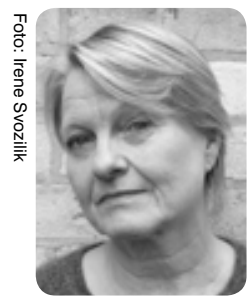

ANNE FREUCHEN, Ph.D., spesialist i psykiatri og barne- og ungdomspsykiatri. Ansatt som overlege og forsker ved Avdeling for barn og unges psykiske helse og i team for selvmordsforebyggende arbeid ved Klinikk for psykisk helse, Sørlandet sykehus HF, Kristiansand. 